\title{
KNOWLEDGE MANAGEMENT AT UKRAINIAN INDUSTRIAL ENTERPRISES IN THE CONTEXT OF INNOVATIVE DEVELOPMENT
}

\author{
SERGII ILLIASHENKo ${ }^{(1)}$ YULIIA SHYPULINA \\ NATALIIA ILLIASHENKO OLENA GRYSHCHENKO \\ ANNA DERYKOLENKO
}

\begin{abstract}
A B S TR A C T
The research aimed to identify promising areas and outline problems associated with the transition of Ukrainian industrial enterprises towards advanced innovative development based on information and knowledge and to formulate recommendations for improving the knowledge management and commercialisation at these enterprises. The study used several methods for analysis, including a literature review; system, structural and statistical analyses; SWOT analysis; the inference method; and interpretation. The research efforts resulted in systemised major sources of knowledge in an enterprise and types of their utilisation. The performed analysis found the key ways to obtain and commercialise knowledge used by Ukrainian industrial enterprises. The results were compared with data of the EU countries. The analysis produced strengths and weaknesses of the existing knowledge management system used in Ukrainian enterprises. Strengths: growth in the number of enterprises producing new knowledge and implementing marketing and organisational innovations; intensified patent activity; and a rational structure of innovation-active enterprises by their size. Weaknesses: the new knowledge structure does not meet the needs of enterprises; an insignificant and unstable share of innovation-active enterprises in the total number of firms; and insignificant sales volumes of patents. The research revealed that Ukrainian enterprises had the potential ability to produce and commercialise new knowledge effectively and to use it as the basis to form, strengthen and implement relative competitive advantages, which would contribute to the innovative growth of the Ukrainian economy as a whole. Recommendations were designed for the formation of prerequisites necessary to improve the efficiency of knowledge management in the context of conditions required for the innovative development of domestic enterprises. The obtained results can be used as an information base for evaluating the system of knowledge production and commercialisation at Ukrainian enterprises to enhance the management and identify promising areas for innovative development.
\end{abstract}

KEY WORDS

knowledge production, knowledge commercialisation, knowledge management in industrial enterprises, innovative development, knowledge economy

pages: $43-56$

Sergii Illiashenko

National Technical University “Kharkiv Polytechnic Institute", Ukraine University of Economics and Humanities, Poland ORCID 0000-0001-5484-9788

Corresponding author: e-mail: illiashenko.s@gmail.com

Yuliia Shypulina

National Technical University “Kharkiv Polytechnic Institute", Ukraine ORCID 0000-0002-8133-578X

Nataliia Illiashenko

National Technical University "Kharkiv Polytechnic Institute", Ukraine ORCID 0000-0002-1426-1215

Olena Gryshchenko

Sumy State Pedagogical University, Ukraine ORCID 0000-0002-4979-9533

Anna Derykolenko

Sumy State University, Ukraine ORCID 0000-0003-4971-5472

\section{INTRODUCTION}

Under modern economic conditions, information and knowledge have become the main means of social production, at the same time representing a significant deterrent to development (cf. for the industrial economics, it is capital) and replacing labour as a source of added value. The availability of relevant knowledge as well as the ability to use it determine the directions and rates of economic growth. The ability to produce and utilise (commer-

Illiashenko, S., Shypulina, Y., Illiashenko, N., Gryshchenko, O., \& Derykolenko, A. (2020). Knowledge management at Ukrainian industrial enterprises in the context of innovative development. Engineering Management in Production and Services, 12(3), 43-56. doi: 10.2478/emj-2020-0018 
cialise) new relevant knowledge is an important competitive advantage for enterprises, as well as the economy as a whole. Effective knowledge management allows enterprises to adapt to continuously changing conditions of the external macro- and micro-environment caused by waves of technological innovations (i.e. the transition from the 5 th to the 6th) and the beginning of the Fourth Industrial Revolution. It also helps to find and implement new market opportunities for innovative development; to produce and commercialise innovative developments; and to compete successfully in national and foreign markets, segments or niches. In the case of the Ukrainian economics, which is based on the production activities representing the third and fourth patterns of technological innovations, the strategic directions of innovative development should be focused on the concept of innovative advancement.

The justification of these directions requires relevant knowledge about the trends in science and technology and the possibility to implement them into product and process innovations that meet consumer demands or shape new needs (for radical innovations). From the standpoint of advanced innovative development of enterprises, the following types of knowledge can be defined as a basis for technology of the Industry 4.0, which can provide innovative advancement: smart technologies (i.e., energy consumption, product informatisation, etc.); product life cycle management; augmented and virtual reality (in product design and testing); production management systems, etc.

However, in Ukraine, only some national producers and distributors of foreign companies sell these technologies. It is also necessary to have knowledge of trends in consumer demand, understand the current and future market opportunities for development, and counter threats.

Given the circumstances, it is relevant to address the problem of improving the efficiency of knowledge management in Ukrainian enterprises in the context of ensuring their innovative development. It becomes especially relevant for industrial enterprises as a leading industry, the development of which determines the pace of scientific and technological progress of the national economy as a whole. An answer to this problem will allow Ukrainian enterprises to purposefully choose the trajectories of advanced innovative development, form and strengthen their competitive advantages, create conditions for sustainable economic growth, and improve the quality of life of the residents of Ukraine.
The structure of the article includes sections that reflect the content of the stages use to solve this problem: a literature review on knowledge management of organisations as a basis for their innovative development; a systematisation of the main sources and areas of knowledge production (acquisition) and knowledge commercialisation in enterprises; the analysis of problems and prospects of the knowledge-centred innovative development of Ukrainian industrial enterprises; a set of recommendations for the creation of prerequisites required to improve the knowledge management system at industrial enterprises of Ukraine.

\section{LITERATURE REVIEW}

Many scientists have focused on knowledge management in organisations, in particular, on possibilities to ensure their innovative development. Blanc and Bouillon (2012) explored the forms, tools, and methods of knowledge management in organisations, as well as matters related to appropriate communication support. They noted that the implementation of knowledge management systems in organisations required organisational change, especially from the perspective of providing the necessary communications. Landry and Amara (2012) explored issues of new knowledge and technology transfer, defined the peculiarities of value creation and transfer. Massingham (2014) evaluated the best practices of knowledge management in 2008-2013. Based on the results of the evaluation, the list of effective and ineffective knowledge management tools was formed, and recommendations for their application were developed. Borjigen (2015) explored the theoretical and methodological foundations of the organisational knowledge management in the context of a significant spread of modern computer information technology of mass cooperation. Khedhaouria and Jamal (2015) analysed the issues related to the motivation of project team members aiming to find knowledge sources as a basis for innovative development.

The problems related to knowledge commercialisation in organisations, as well as products created based on new knowledge, are popular topics among researches (Bandarian, 2007; Markman at al., 2008; Formánek, 2015; Maceika \& Jančiauskas, 2012; Stankiewicz \& Moczulska, 2015; Majewska \& Sulczynska, 2014; Fitri et al., 2019; Aymen, 2019). Scientists pay considerable attention to the analysis of 
factors influencing the success of knowledge commercialisation. Some authors (Zahra et al., 2018) emphasise the importance of scientific research as a source of knowledge but note that such scientific research receives little attention. Yahiaei and Hasanzadeh (2018) determined the factors of the external macro- and micro-environment that contribute to the commercialisation of information and computer technologies in IT. Other researchers (Fini et al., 2018) explored the theoretical aspects of the commercialisation of research results, as well as the impact of commercialisation on various aspects of social activities. In their article, Prokopenko et al. (2018) outlined a new role of universities in knowledge generation under the conditions of post-industrial society.

Naqshbandib and Jasimuddin (2018) analysed the activities of 172 multinational companies operating in the French market. In analysed companies, the authors substantiated a positive impact of knowledgecentred leadership on the effectiveness of knowledge management and innovative activity. Mardania et al. (2018) presented the results of the quantitative analysis into the impact of knowledge management on the innovative activity of a firm and the effectiveness of its work as a whole. A model was built and practically tested at 120 companies of the Iranian Energy Syndicate. The obtained results proved a positive impact of knowledge management on the effectiveness of innovation processes of a company, and ultimately - on the economic efficiency of its activities. Downs et al. (2019) developed conceptual principles of the approach to improving the business model of commercialisation of innovations in knowledge-intensive industries. Ringel et al. (2018) performed a retrospective analysis from 2006 to 2018 of the change dynamics in the positions of the most innovative companies in the world. Companies were divided into following categories: steady innovators - companies that appear on the list annually; movers - companies that have improved by ten positions or more in 2015-2016; new entrants - companies that first appeared on the list in 2016; returnees - companies that returned to the list in 2016 after elimination in 2015 or earlier. The analysis substantiated the dynamics of a market position held by innovative companies, indicated the options for strengthening the competitive position of existing market players and defined the possibility for new players to enter the innovative market, etc.

Ukrainian scientists study problems related to the improvement of knowledge commercialisation methods of enterprises in the context of ensuring their innovative development. Kovtunenko (2012) considered the essence and content of the commercialisation process for innovative developments in high-tech enterprises, the main stages, and participants of the commercialisation process, and existing ways for the commercialisation of innovations. Kuzmin and Kostsyk (2013) analysed the forms and methods for commercialisation of innovative products, related advantages and disadvantages. They developed a model that helps to choose methods for the commercialisation of innovative products. Olefirenko $(2016,2017)$ considered the peculiarities of sales as a component pertaining to the process of commercialisation of innovative products in machine-building enterprises. Rot-Sierov (2016) revealed the role and place of knowledge in the process of the commercialisation of industrial enterprise innovations.

However, despite significant developments, insufficient efforts have been made to investigate the issues related to the analysis into the effectiveness of knowledge management considering the specificity of Ukrainian industrial enterprises. Foreign solutions do not provide the desired result without proper adaptation to the conditions of Ukraine, and the Ukrainian solutions are fragmentary and consider only some aspects of knowledge management. Almost no studies are available that systematically consider the actual state of the processes of production (acquisition) and utilisation (commercialisation) of knowledge and their variety. Such a situation does not allow Ukrainian enterprises to perform their comparative analyses, identify the relative advantages and disadvantages, and on this basis, offer recommendations for improving the efficiency of knowledge management from the perspective of ensuring their innovative development.

\section{RESEARCH METHODS}

This research was based on a complex methodological approach; namely, a literature review, a comparative analysis, and a systems and structural analyses were used to systematise the methods for producing (acquiring) and utilising (commercialising) knowledge at an industrial enterprise, to develop a scheme for a compatible interaction of incoming and outgoing knowledge flows. The systems analysis based on data by the State Statistic Service of Ukraine contributed to the study regarding the main sources for the acquisition of knowledge used by Ukrainian 
industrial enterprises and types of their utilisation. The analysis of data provided by the State Statistic Service of Ukraine and international organisations was used to determine the position of Ukraine in the system of innovation-active countries of the world and Europe. A SWOT analysis was made to assess market opportunities, threats, strengths, and weaknesses of the knowledge management system used by Ukrainian industrial enterprises. It also aimed to identify promising areas for gaining comparative competitive advantages that could serve as a basis for the transition to advanced innovations. Inference and interpretation methods were used to develop a set of recommendations for the design of prerequisites necessary to improve the management system of production and commercialisation.

\section{RESEARCH RESULTS}

The analysis into literature sources and innovative activities undertaken by enterprises allowed systematising the main methods of the production (acquisition) and utilisation (commercialisation) of knowledge used by industrial enterprises.

Fig. 1 presents the scheme for the production (acquisition) and utilisation (commercialisation) of knowledge at industrial enterprises, which was devel- oped by the authors of this article based on the results of the analysis. The arrows in the scheme show the directions of knowledge flows (ordinary arrows indicate the sources of knowledge, bold arrows - the directions of knowledge utilisation). Fig. 1 shows that knowledge can be obtained from both internal and external sources (names of knowledge sources are indicated in regular font). Also, the directions are given for the knowledge utilisation at an enterprise, as well as externally (the names of directions of knowledge utilisation are indicated in italics).

It should be noted that the authors consider knowledge as a set of ordered rules and facts, which allows solving problems in a particular subject area. Knowledge is an intellectual commodity and an object of market exchange. From the whole set of knowledge, the authors explored the formalised documented knowledge (both theoretical and empirical), in particular, technical and technological knowledge presented as patents, algorithms, technologies, drawings, etc.; professional knowledge embodied in skills, know-how, work techniques, skills, experience, etc.; scientific knowledge presented in ideas, theories, hypotheses, patterns, laws, concepts, etc.

The proposed scheme provides a systems analysis of the main knowledge sources and areas of knowledge utilisation in Ukrainian enterprises. The authors used official data of the State Statistics Service of

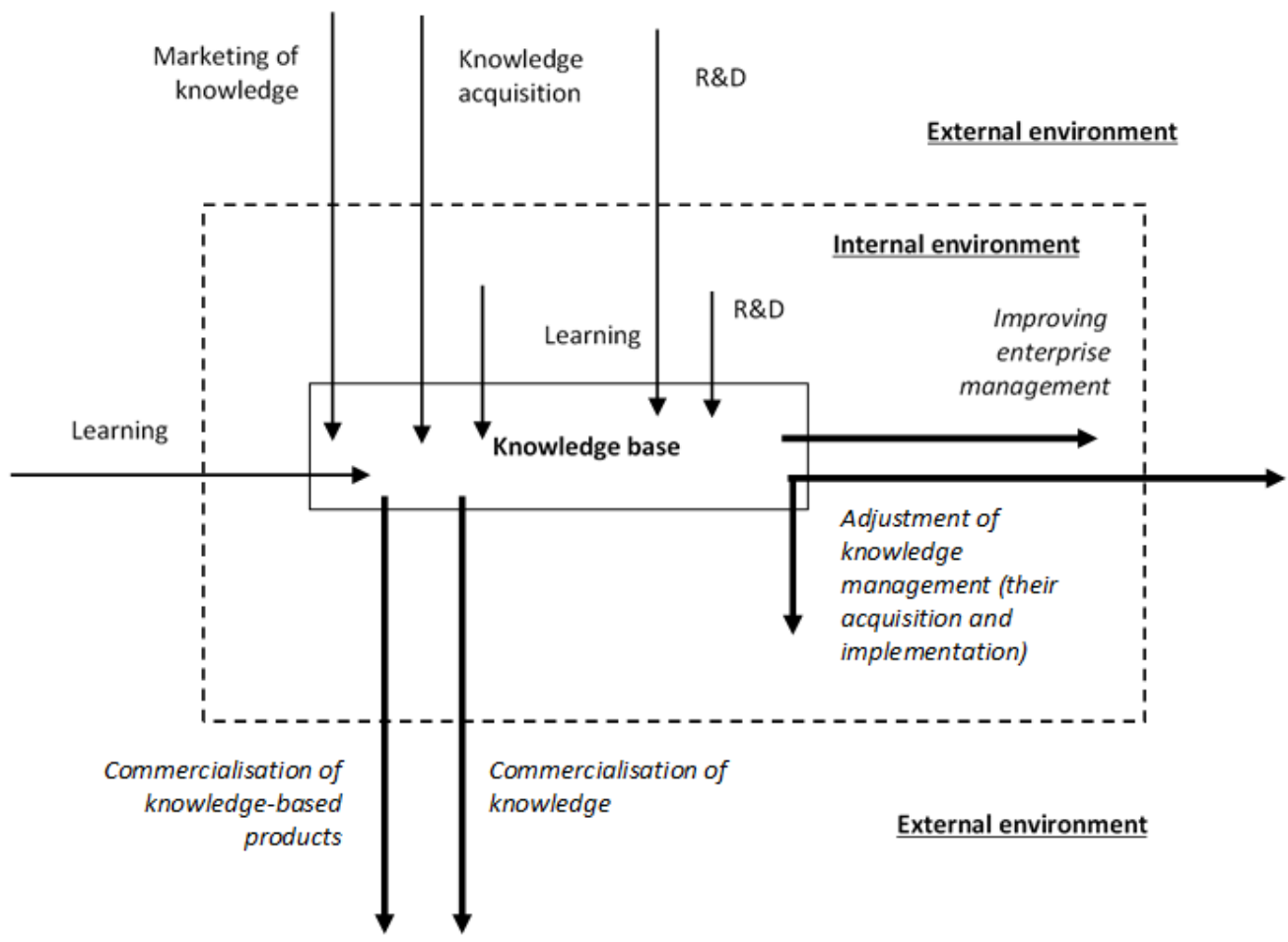

Fig. 1. Scheme depicting the production (acquisition) and utilisation (commercialisation) of knowledge at industrial enterprises 
Ukraine (Scientific and Innovative Activity of Ukraine, 2018; 2019) as a basis for analysis. Information provided by the international analytical organisations was also used to compare the Ukrainian realities of innovative development with the European.

Fig. 2 summarises the results of the analysis, which defines the main sources of new knowledge used by innovative Ukrainian enterprises in 20122016.

Figs. 3 and 4 provide information on the new knowledge sources of Ukrainian industrial enterprises. The percentage in Figs. 3 and 4 represent shares of enterprises that received knowledge from these sources in the total number of firms that implement technological innovations. The diagrams were constructed according to the international methodology, using statistical data from the survey regarding the innovation activity in the economy of Ukraine (Scientific and Innovative Activity of Ukraine, 2018). In the total number of surveyed enterprises, the share of enterprises with technological innovations (2663 in 2012-2014; 3278 in 2014-2016; and 2937 in
2016-2018) was $9.5 \%$ in $2012-2014$; $11.8 \%$ in $2014-$ 2016; and $10.1 \%$ in 2016-2018.

A significant share of innovation-active enterprises that had technological innovations received knowledge via staff training in 2012-2014, but in 2014-2016, the priorities changed in favour of the $\mathrm{R} \& \mathrm{D}$ implementation.

However, according to the Annual Business Climate Assessment conducted by the Institute for Economic Research and Policy Consulting within the USAID Programme "Leadership in Economic Governance" (Annual Assessment of the Business Climate, 2016), the lack of skilled workers is one of the obstacles to the further development of domestic enterprises (this statement was confirmed by $20 \%$ of respondents).

According to another study (Industry 4.0 in the Machine-Building Industry, 2018), insufficient knowledge and skills of staff and management are the main factors that hinder the implementation of Industry 4.0 technologies.

Fig. 5 presents the expenditure volumes by areas of innovative activity in 2000-2019. According to

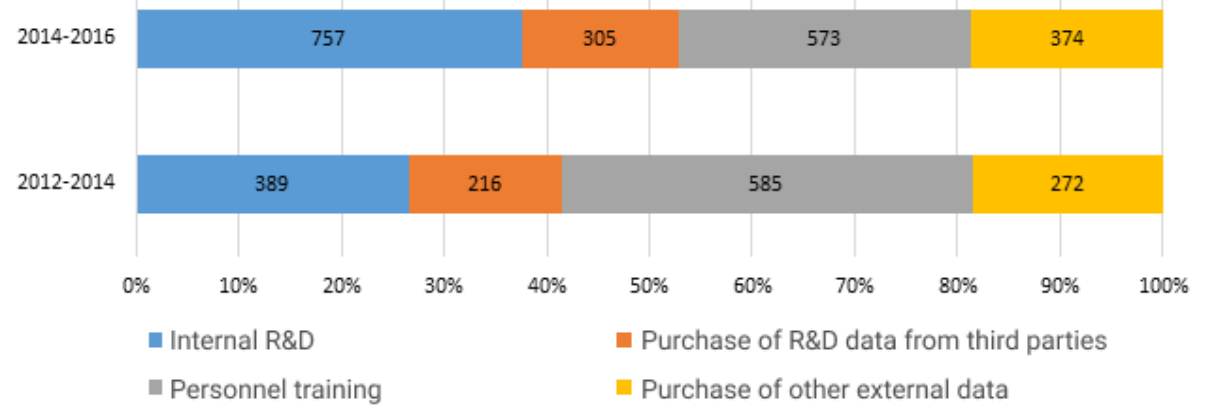

Fig. 2. Percentage distribution of innovation-active enterprises that create technological innovations (by the sources of knowledge)

Source: elaborated by the authors based on Scientific and Innovative Activity of Ukraine (2018).

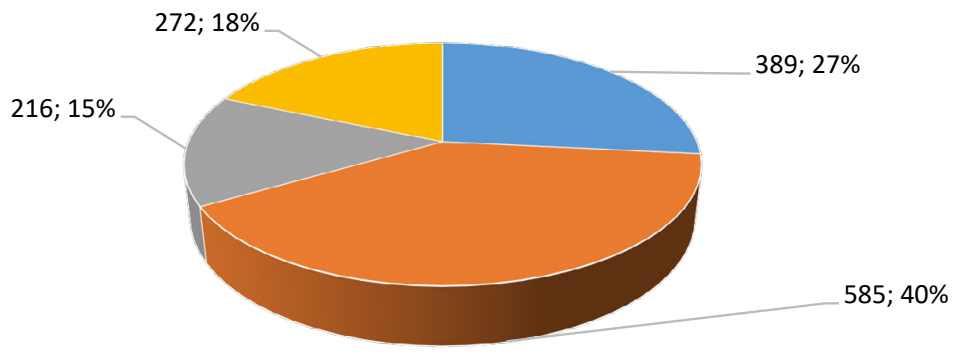

-R\&D $\quad$ Personnel training $\quad$ Purchase of the R\&D data $\quad$ Purchase of other external knowledge

Fig. 3. Structure of Ukrainian enterprises that created technological innovations in 2012-2014

(by the sources of new knowledge)

Source: elaborated by the authors based on Scientific and Innovative Activity of Ukraine (2018). 


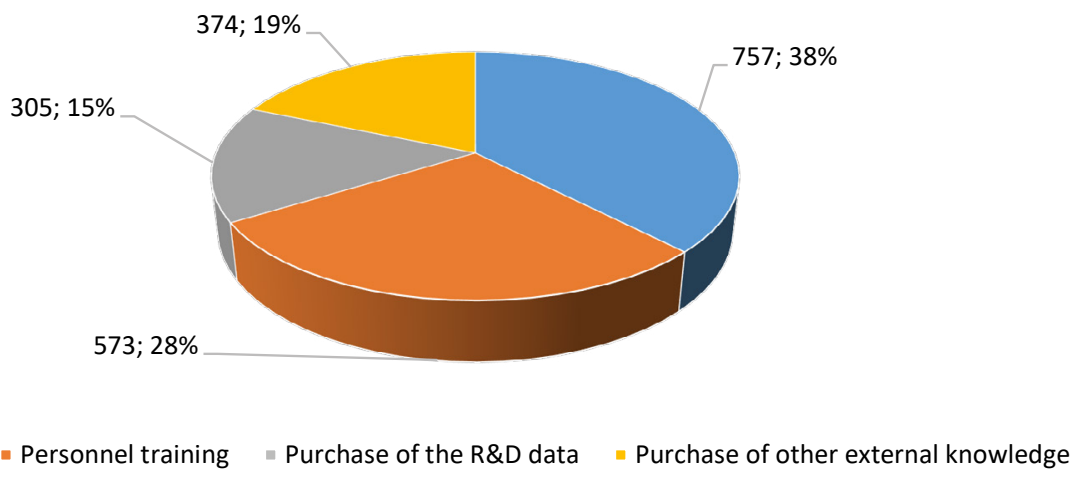

-R\&D $\quad$ Personnel training $\quad$ Purchase of the R\&D data $\quad$ Purchase of other external knowledge

Fig. 4. Structure of Ukrainian enterprises that created technological innovations in 2014-2016

(by the sources of new knowledge)

Source: elaborated by the authors based on Scientific and Innovative Activity of Ukraine (2018).

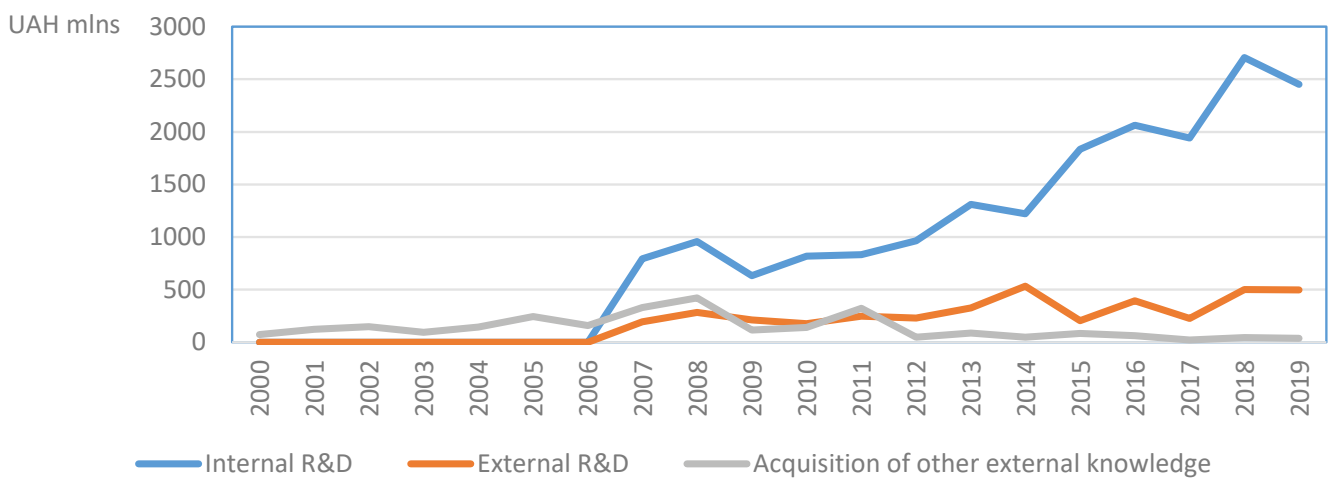

Fig. 5. Expenditures volumes by areas of innovative activity in 2000-2019

Source: elaborated by the authors based on the State Statistics Service of Ukraine (2019).

statistical reports, the cost of acquiring external knowledge is insignificant compared to other sources of knowledge, and it tends to decrease. It should be noted that in 2017, compared to 2016, the expenditure volumes decreased in all categories. Thus, the expenditures on internal research decreased by $6 \%$, external research - by $42 \%$, and the acquisition of external knowledge - by $66 \%$. In 2018 , the first two areas showed positive dynamics, while the expenditures on acquiring external knowledge remained substantially unchanged. 2019 saw a significant decrease in expenditures of all categories: the funding for domestic research decreased from UAH 2706.2 million in 2018 to UAH 2449.9 million in 2020 (almost 9.5\% less), the funding for external research - by $1.3 \%$, and the funding for the acquisition of other external knowledge - by $18.7 \%$.

The use of marketing knowledge as a source of information for innovative activity can be described as follows. According to Scientific and Innovative Activity of Ukraine (2018), all enterprises that implemented technological innovations in 2014-2016 used the following knowledge sources (ideas were obtained using tools for knowledge marketing and innovative marketing): research finding employees; suppliers of raw and other materials, etc.; consumers; universities; state research institutes; conferences, fairs, exhibitions; magazines or advertising publications; professional or industrial associations. The allocation of enterprises by sources of innovative developments is shown in Fig. 6.

Knowledge commercialisation can have different purposes. The main areas of knowledge commercialisation at an enterprise can be suggested based on Fig. 1 :

- the commercialisation of intellectual property objects/products (i.e., patents, licenses, utility models, industrial designs, etc.), which represent new knowledge;

- the commercialisation of new products/services, which represent new knowledge;

- improvement of the enterprise management system (organisational structure; personnel management; organisational culture; supply system of raw materials, materials, and components; innovation activities; financial and economic activi- 


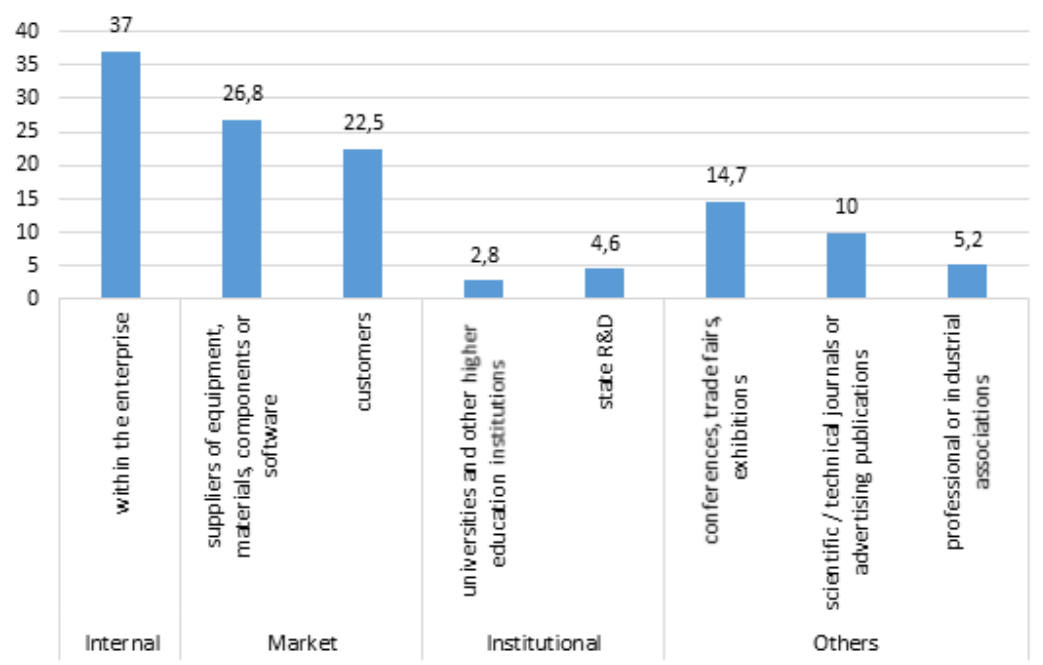

Fig. 6. Innovative development sources used by Ukrainian enterprises that created technological innovations in 2014-2016, \%

Source: elaborated by the authors based on Scientific and Innovative Activity of Ukraine (2018).

ties; marketing, etc.), which increases the competitiveness and efficiency of commercialisation of products on traditional or new markets;

- a combination of the above-mentioned options.

It is also important to consider the domestic realities of knowledge commercialisation (as a factor contributing to the development of enterprises) in the framework of the above-mentioned areas.

\subsection{COMMERCIALISATION OF INTELLECTUAL PROPERTY OBJECTS/PRODUCTS}

According to Bloomberg (2019), in 2018-2019, Ukraine ranked 35th in the world by the number of granted patents; this means that according to this indicator, Ukraine was in the top-50 of most innovative world economies.

In 2017, a record number of patent applications (3.17 million) was filed worldwide. China and Turkey showed an increase in the number of applications (increasing by $14.2 \%$ and $24.9 \%$, respectively), becoming the only two countries to achieve doubledigit growth. Turkey ranked 20th in 2017 and improved its ranking compared to 2016 ( +3 ranking places) (Turkey: WIPO Releases, 2018).

According to the World Intellectual Property Organization (2019), in 2017, Ukraine ranked 4th in the world (falling behind China, Germany, and the Russian Federation) by the number of applications for registration of utility models, and 15th by the number of applications for registration of industrial designs.

The dynamics of patent activity in Ukraine is presented in Table 1.However, the sales of patents are much worse. According to Scientific and Innovative Activity of Ukraine (2018), only 59 new technologies were transferred on a commercial basis within

Tab. 1. Patent activity of Ukrainian applicants: legal entities and individuals

\begin{tabular}{|c|c|c|c|c|c|}
\hline \multirow{2}{*}{\multicolumn{2}{|c|}{$\begin{array}{c}\text { OBJECTS } \\
\text { OF INTELLECTUAL PROPERTY }\end{array}$}} & \multicolumn{4}{|c|}{ A NUMBER OF APPLICATIONS/PATENTS PER YEAR } \\
\hline & & \multirow{2}{*}{2010} & \multirow{2}{*}{$\begin{array}{r}2015 \\
2273\end{array}$} & \multirow{2}{*}{$\begin{array}{r}2016 \\
2232\end{array}$} & \multirow{2}{*}{$\frac{2017}{2285}$} \\
\hline & Applications & & & & \\
\hline काष & Patents & 2034 & 1510 & 1277 & 1224 \\
\hline \multirow{2}{*}{ Useful models } & Applications & 10528 & 8490 & 9473 & 8977 \\
\hline & Patents & 9229 & 8035 & 8931 & 9365 \\
\hline \multirow{2}{*}{ Industrial designs } & Applications & 1442 & 1811 & 2016 & 2249 \\
\hline & Patents & 1258 & 1957 & 2134 & 2113 \\
\hline \multirow{2}{*}{ Trademarks } & Applications & 1671 & 21245 & 26064 & 26276 \\
\hline & Patents & 13058 & 9539 & 11007 & 12989 \\
\hline
\end{tabular}

Source: elaborated by the authors based on Scientific and Innovative Activity of Ukraine (2018). 
Ukraine in 2017 (in addition to patents, they also include other intellectual property objects, in particular, know-how).

Information regarding the export of intellectual property is closed and not covered in statistical reporting.

An assumption can be made that intellectual property objects were implemented at applicant companies, but no data is available regarding their number.

\subsection{COMMERCIALISATION OF KNOWLEDGE IN THE FORM OF NEW PRODUCTS, TECHNOLO- GIES, AND METHODS OF MARKET PROMOTION}

Fig. 7 shows the allocation of Ukrainian innovation-active enterprises engaged in the manufacture and promotion of innovative products on the market, improvement of management methods at all stages of creation, and the commercialisation of products.

In 2016-2018, the number of innovation-active enterprises continued growing in all three categories and reached 5097 (62.4\%) small, 2140 (26.2\%)

2012-2014

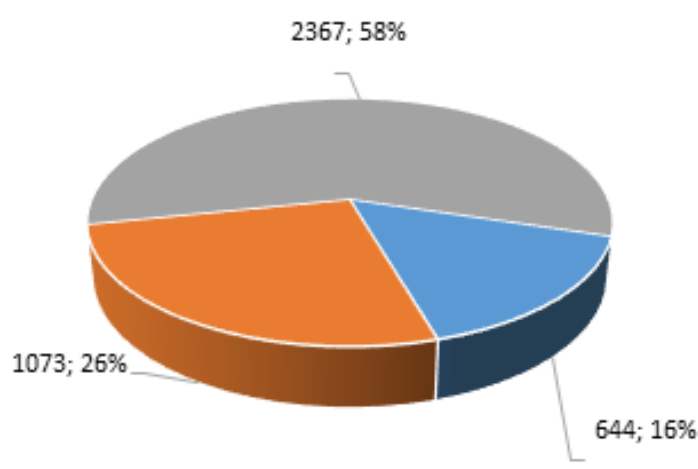

medium, and 936 (11.4\%) large firms. At the same time, the share of small and medium-sized enterprises was constantly growing while the share of large firms was decreasing.

According to Eurostat (2019), the share of small enterprises in the total number of innovation-active firms was $68 \%$, while medium companies comprised $24 \%$ and large - about $7 \%$.

Table 2 shows the allocation of Ukrainian innovation-active enterprises engaged in technological innovations (Scientific and Innovative Activity of Ukraine, 2018, 2019). In 2012-2014, 1421 enterprises implemented organisational and marketing innovations (34.5\% of the total number of innovative firms); in 2014-2016, this figure amounted to1817 (35.7\%); and in 2016-2018, it was $5236(64.1 \%)$.

Thus, there is an increase in organisational and marketing innovations and a decrease in the share of technological innovations. This indicates an improvement in the organisation of market-centred activities of innovative enterprises. These data also indicate trends in the technological backwardness of Ukrainian enterprises.

2014-2016

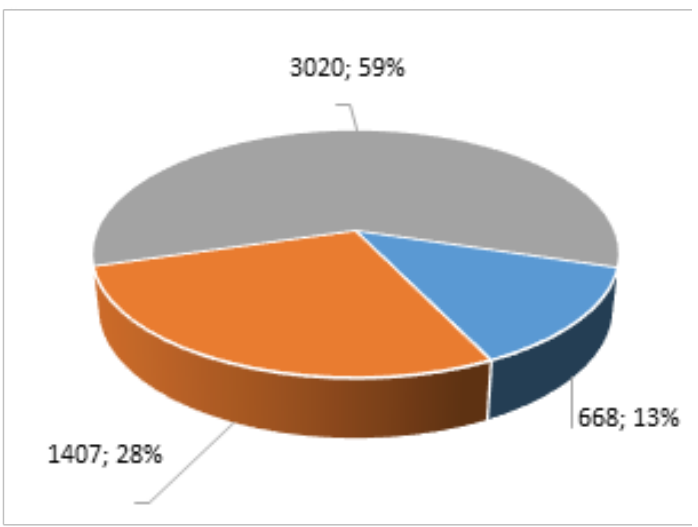

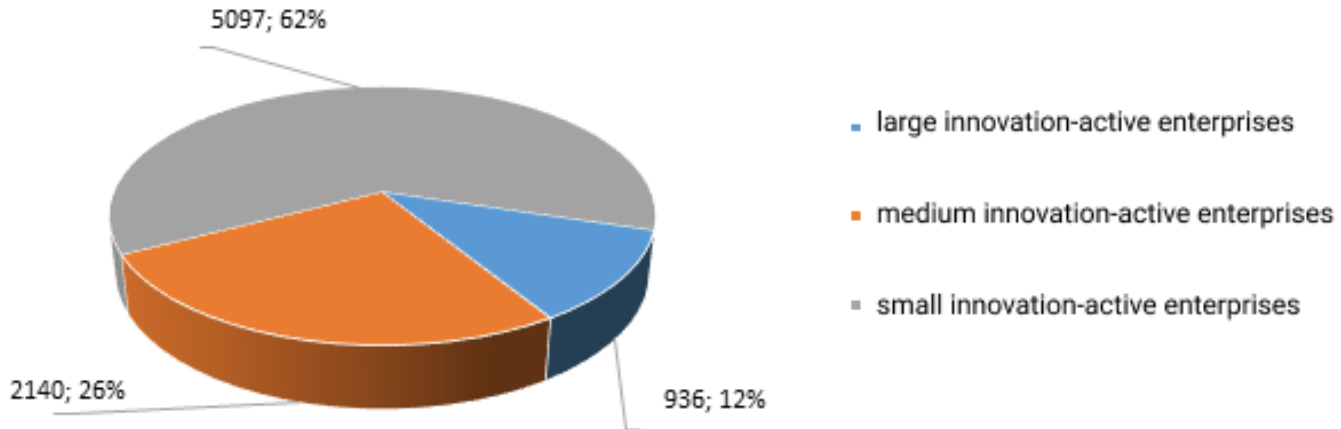

Fig. 7. Innovation-active enterprises of Ukraine grouped by their size

Source: elaborated by the authors based on Scientific and Innovative Activity of Ukraine (2018). 
Tab. 2. Types of technological innovations implemented by Ukrainian enterprises

\begin{tabular}{|c|c|c|c|c|}
\hline \multirow{2}{*}{\multicolumn{2}{|c|}{ INDICATORS OF INNOVATIVE ACTIVITY }} & \multicolumn{3}{|c|}{ YEARS } \\
\hline & & 2012-2014 & 2014-2016 & $2016-2018$ \\
\hline \multicolumn{2}{|c|}{ Enterprises that implemented technological innovations, total number } & 2663 & 3278 & 2937 \\
\hline \multirow{2}{*}{ Product innovations only } & Number & 446 & 347 & 765 \\
\hline & $\%$ & 16.7 & 10.6 & 26.0 \\
\hline \multirow{2}{*}{ Process innovations only } & Number & 1003 & 1601 & 1038 \\
\hline & $\%$ & 37.7 & 48.9 & 35.3 \\
\hline \multirow{2}{*}{ Product and process innovations } & Number & 1008 & 1260 & 1134 \\
\hline & $\%$ & 37.9 & 38.4 & 38.7 \\
\hline \multirow{2}{*}{ Continuous and interrupted innovations } & Number & 206 & 70 & - \\
\hline & $\%$ & 7.7 & 2.1 & . \\
\hline
\end{tabular}

Source: elaborated by the authors based on Scientific and Innovative Activity of Ukraine $(2018,2019)$.

\subsection{Problems AND PROSPECTS Of KNOWL- EDGE-CENTRED INNOVATIVE DEVELOPMENT OF UKRAINIAN ENTERPRISES}

According to Scientific and Innovative Activity of Ukraine $(2018,2019)$, the total number of innovationactive industrial enterprises in 2012-2014 was 2492 (60.0\% of all innovation-active enterprises); in 20142016, the figure amounted to 2598 (51.0\%); and in 2016-2018, it was 4060 (49.7\%). In other words, there was a constant decline in the share of innovation-active industrial enterprises in comparison with the increase in the total number of enterprises. For comparison, in the EU, more than $50 \%$ of the total number of enterprises are innovation-active, and in the leading countries, this figure can be as high as $70 \%$ and more (Eurostat, 2019).

2387 innovative products were introduced by Ukrainian innovation-active industrial enterprises, namely, 477 exclusive innovations that were new for the market and 1910 innovations that were only new for the enterprise. Of the total number of introduced products, 751 were new types of machines, equipment, devices, machines, etc., 229 of which were new to the market (Scientific and Innovative Activity of Ukraine, 2018). Compared to 2015, the indicators decreased almost twice, which indicates the growing lag of Ukraine in innovations. In 2018, there was a slight increase in these indicators (3848 innovative products were introduced to the market, 968 of which were new to the market). 920 types of new machines, equipment, etc. were introduced to the market, 271 of which were new to the market. Such fluctuations indicate the lack of clear trends in the commercialisation of innovations of domestic industrial enterprises, as well as the ambiguity in the development of the knowledge management system that underlies these innovations.
This can be corroborated by data of international organisations describing Ukraine's position in the ranking of innovations. According to the European Innovation Scoreboard (2018), all European countries belong to four groups according to the innovation performance: 1 - innovation leaders; 2 - strong innovators; 3 - moderate innovators; and 4 - modest innovators. Switzerland demonstrated the best innovation performance by scoring 169.43 points, while Ukraine showed the worst result with 28.63 points. The average level of innovation activity was 105.8 points. However, according to Cornell University, INSEAD Business School, and the World Intellectual Property Organization, Ukraine was ranked 43rd out of 126 in 2018 (The Global Innovation Index, 2019). The ranking of Ukraine increased by 13 positions compared to 2016 (Ukraine in the Global Ranking of Innovations, 2016).

However, there are some reasons to be cautiously optimistic. According to one indicator (i.e., the percentage of the population aged 30-34 who have completed higher education), Ukraine is above the European average. According to Bloomberg (2019), Ukraine has fairly high scores for two indicators (out of 6) that affect the country's innovative development trends, i.e., 21 for the effectiveness of higher education; and 32 for a concentration of high-tech and research enterprises and companies. This indicates the potential ability to produce and commercialise new knowledge that is the basis for innovation.

\section{DISCUSSION OF THE RESULTS}

External and internal conditions had to be analysed to identify promising areas and potential problems related to the transition of Ukrainian industrial 
enterprises towards advanced knowledge-centred innovative development. The SWOT analysis was used for this purpose. The degree of conformity was estimated between internal conditions of the advanced knowledge- centred innovative development and external conditions.

The generalisation of the analysis results indicates the presence of both positive and negative characteristics of the production system and the use of knowledge at Ukrainian industrial enterprises. Table 3 presents the most significant findings for the transition of industrial enterprises towards advanced innovative development.

Table 4 presents the main market opportunities and threats pertaining to the innovative development of domestic industrial enterprises based on the results of the analysis into the Ukrainian innovation system as well as global economic trends.

The research findings presented in Tables 4 and 5 indicate the presence of external and internal opportunities for the advanced knowledge-centred innovative development of Ukrainian industrial enterprises.
The most promising external (market) opportunities are listed in Table 5 (opportunities 1, 2, and 3). Their implementation is facilitated by the strengths of the knowledge management system (Table 4 , strengths 1 and 4).

Illiashenko and Rot-Sierov (2016) noted that the possibility for the domestic economy to transit towards advanced innovation was based on the production and commercialisation of new knowledge as a major factor in the formation, strengthening and implementation of competitive advantages. It contributes to the growth of the domestic economy, and consequently, the well-being and quality of life of the Ukrainian population. This fact was confirmed by Shypulina (2017), who's research substantiated the close stochastic convergence between the country's Global Innovation Index and GDP per capita (Fig. 8).

Nevertheless, the presence of relatively strong external market threats (Table 5, threats 1,2), as well as the weaknesses of the knowledge management system (Table 4, weakness 3 ) indicate the difficulties related to the implementation of strategies for transit

Tab. 3. Strengths and weaknesses of knowledge management in industrial enterprises of Ukraine

\begin{tabular}{|l|l|}
\hline \multicolumn{1}{|c|}{ STRENGTHS } & \multicolumn{1}{|c|}{ WEAKNESSES } \\
\hline $\begin{array}{l}\text { 1. A growing number of enterprises with technological in- } \\
\text { novations that actively produce (acquire) new knowledge. } \\
\text { There is an increase (unstable) in the cost of producing } \\
\text { (acquiring) new knowledge }\end{array}$ & $\begin{array}{l}\text { 1. The share of innovative firms in the total number of enterprises is } \\
\text { insignificant }\end{array}$ \\
\hline $\begin{array}{l}\text { 2. The patent activity has positive trends, especially con- } \\
\text { cerning applications for registration of utility models and } \\
\text { industrial designs }\end{array}$ & 2. The sales of patents are insignificant \\
\hline $\begin{array}{l}\text { 3. The structure of innovation-active enterprises by their } \\
\text { size corresponds to the average European trend. There is } \\
\text { an increase in the number of all categories of innovative } \\
\text { enterprises }\end{array}$ & $\begin{array}{l}\text { 3. The structure of the acquired new knowledge is irrational, given the } \\
\text { existing needs of enterprises }\end{array}$ \\
\hline $\begin{array}{l}\text { 4. The number of enterprises implementing marketing and } \\
\text { organisational innovations is growing }\end{array}$ & $\begin{array}{l}\text { 4. The fluctuations occur in the number of enterprises implement- } \\
\text { ing technological innovations. There are no tendencies showing their } \\
\text { growth }\end{array}$ \\
\hline
\end{tabular}

Tab. 4. Opportunities and threats of knowledge management in industrial enterprises of Ukraine

\begin{tabular}{|c|c|}
\hline OPPORTUNITIES & THREATS \\
\hline $\begin{array}{l}\text { 1. The needs of production and commercialisation of new } \\
\text { knowledge that serve as the basis for innovation: intellec- } \\
\text { tual property, innovative products, and technologies }\end{array}$ & $\begin{array}{l}\text { 1. The weakness of the national innovation system: low effectiveness of } \\
\text { state regulation and stimulation of innovative activities; an underdevel- } \\
\text { oped innovation infrastructure, etc. }\end{array}$ \\
\hline $\begin{array}{l}\text { 2. The existence of competitive advantages in certain } \\
\text { industries, which will allow implementing the strategy of } \\
\text { advanced innovation development }\end{array}$ & $\begin{array}{l}\text { 2. Almost no state industrial policy, the tendency to deindustrialise the } \\
\text { country }\end{array}$ \\
\hline $\begin{array}{l}\text { 3. Enhancing problems that cannot be solved with the } \\
\text { help of existing equipment and technologies and manage- } \\
\text { ment methods. This creates opportunities for innovative } \\
\text { breakthroughs as a way to solve problems }\end{array}$ & $\begin{array}{l}\text { 3. The growing technological gap between Ukraine and the developed } \\
\text { countries }\end{array}$ \\
\hline $\begin{array}{l}\text { 4. Encouraging the return of qualified personnel who have } \\
\text { knowledge, experience, and connections abroad; encour- } \\
\text { aging the creation of small and medium-sized industrial } \\
\text { enterprises }\end{array}$ & $\begin{array}{l}\text { 4. Threats of the global economic crisis and economic recession in } \\
\text { world markets }\end{array}$ \\
\hline
\end{tabular}




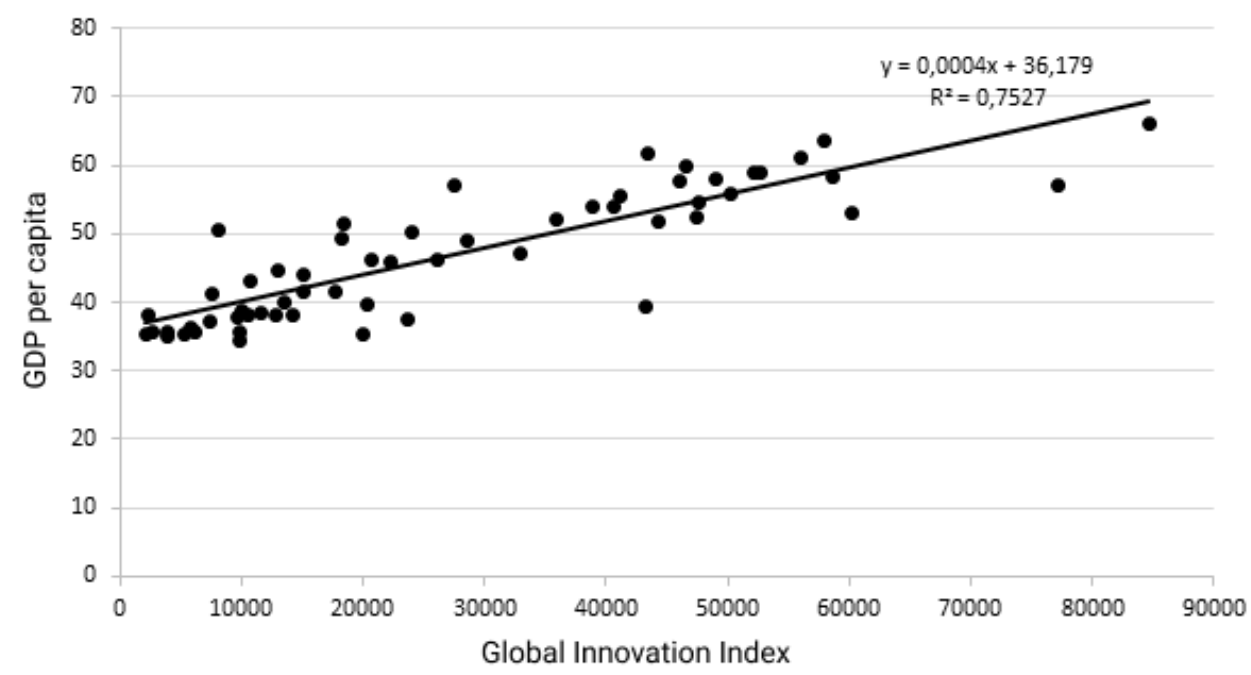

Fig. 8. Stochastic convergence between the country's Global Innovation Index and GDP per capita Source: Shypulina (2017).

towards advanced knowledge-centred innovative development.

The transition of domestic enterprises towards advanced innovative development requires significant adjustments to the mechanisms shaping the innovation-friendly environment both at the state level and at the level of individual enterprises. This is evidenced by the results of the analysis into monographs devoted to the search of ways to transition the Ukrainian economy (with the industrial sector as the leading industry) towards sustainable innovations. The results reveal various aspects of this problem: institutional and structural changes in the country's economy (Soskin, 2014); the development of innovative culture for industrial enterprises as a mechanism for the socio-cultural regulation of staff behaviour (Shypulina, 2017; Bučková, 2015); the improvement of intellectual capital management mechanisms of the enterprise, including such components as knowledge; the management of the commercialisation of innovative engineering products; theoretical and methodological approaches to the management of potential sales of machine-building enterprises (Olefirenko, 2017); the management of marketing channels for the promotion and distribution of innovative products of industrial enterprises (Bilovodska, 2018) etc.

Accordingly, the improvement of mechanisms used by the state to encourage and regulate innovative activities, should be aimed at the elimination or minimisation of market threats, which are listed in Table 5.

The analysis of Tables 4 and 5 enables to form a set of recommendations for improving knowledge management at the level of individual enterprises in the context of conditions required for their advanced innovative development. In particular, a set of the following measures is proposed to rectify the weaknesses of the knowledge management system (Table 4):

- monitoring consumer problems of a specific enterprise and within the related industries (using methods and tools of knowledge marketing; Fig. 1);

- monitoring the recent achievements in science and technology that affect the performance of the enterprise and related industries; analyse their use and create product and process innovations that can solve consumer problems and strengthen the market position of the enterprise (monitor printed and electronic publications, $R \& D$ reports, training deliverables; Fig. 1).

The implementation of the measures will help to place consumer needs and the needs of the enterpriseinnovator at the centre of the system for the acquisition and commercialisation of knowledge. It will also help to reduce the technological backlog of Ukrainian enterprises (Table 5, market threat 3 ).

The above-mentioned actions and activities aimed at the improvement of mechanisms for state regulation and incentives strive to reduce the weaknesses in the knowledge management system of industrial enterprises.

Consequently, the choice of knowledge-centred areas for the advanced innovative development of industrial enterprises of Ukraine should be based on the possibility to implement the existing relative competitive advantages (Table 5, market opportunity 
2). The set of competitive advantages is rather significant for certain industries, such as aerospace; shipbuilding; mechanical engineering (equipment for energy and petrochemical industries); military industry, etc. Enterprises representing these industries (having a highly dynamic allocation of market forces) have a significant opportunity to use innovative products and occupy strong positions in regional and global markets. The results of the BCG analysis into the dynamics of market positions of the most innovative companies in the world (Ringel at al., 2018) testify in favour of the possibility to implement these changes. Their implementation requires legislative consolidation of the State Industrial Policy as one of the main priorities, as well as the improvement of the National Innovation System (Illiashenko, 2019) etc.

\section{CONCLUSIONS}

In summary, it should be noted that the results of the analysis into the main ways used by domestic enterprises to acquire and utilise (commercialise) knowledge indicate contradictory trends. On the one hand, they show a still significant but declining potential for innovative development of Ukrainian enterprises (especially industrial) in terms of the ability to acquire (produce) new relevant knowledge, which serves as a basis for competitive advantages and implement strategies of advanced innovative development. This is especially true for knowledge in the form of industrial property. On the other hand, the results indicate a lag in the realisation of the existing potential of innovative development, which manifests as the deterioration of the innovation activity in domestic enterprises.

The research results can be used as the base of information for estimating the vector of influence made by an existing system for the production (acquisition) and utilisation (commercialisation) of knowledge by enterprises on the innovative development of the Ukrainian economy. They can also serve as the base of knowledge for the management system aimed at choosing the promising areas of innovative development of these enterprises.

The SWOT analysis allowed authors to identify the strengths and weaknesses of the knowledge management system in industrial enterprises, as well as to outline the existing market opportunities and threats. The results of the analysis were considered to develop recommendations for the formation of prerequisites required to improve the efficiency of knowledge management both at the state level and at the level of individual enterprises. The recommendations consider conditions required for the knowledge-centred and advanced innovative development.

Further research should be aimed at the accumulation, systematisation, and analysis of statistical data that characterise innovative processes in Ukraine according to international methodology, to build econometric models that characterise the relationship between the production (acquisition) and utilisation (commercialisation) of knowledge. Their results can be used as a basis to design methodological tools for organisational and economic management of domestic enterprises based on formalised knowledge management procedures to ensure innovative development.

\section{ACKNOWLEDGEMENTS}

The paper was produced with the help of the funding by the Ministry of Education and Science of Ukraine allocated for research topics SR 0118 U003572 "The development of a mechanism for the commercialisation of innovative products"; SR 0117 U003928 "The management mechanism for the design of strategies for outstripping the innovative development of industrial enterprises"; SR 0119U100179 "The development of scientific and methodological foundations and practical tools for evaluating the commercial (market) prospects of product innovations"; and SR 0120U100884 "The social and ethical marketing concept as a tool for ensuring sustainable development".

The paper was written in the framework of the research "The management mechanism of innovative development strategies in the transformation of technological cycles" executed by the University of Economics and Humanities (Bielsko-Biala, Poland).

\section{LITERATURE}

Aymen R. A., Alhamzah, A., \& Bilal, B. (2019). A MultiLevel Study of Influence Knowledge Management Small and Medium Enterprises. Polish Journal of Management Studies, 19(1), 21-31.

Bandarian, R. (2007). Evaluation of commercial potential of a new technology at the early stage of development with fuzzy logic. Journal of Technology Management and Innovation, 2(4), 73-85.

Bilovodska, O. A. (2018). Marketynhova polityka rozpodilu innovatsiynoyi produktsiyi promyslovykh pidpryy- 
emstv [Marketing policy of distribution of innovative products of industrial enterprises]. Kyiv, Ukraine: Centr uchbovoi literatury.

Blanc, B. L., \& Bouillon, J. L. (2012). Organizational devices for knowledge management: Proposal for a crossover perspective between knowledge sciences and communication sciences. VINE: The journal of information and knowledge management systems, 42(3/4), 382-395. doi: 10.1108/03055721211267503

Borjigen, C. (2015). Mass collaborative knowledge management: Towards the next generation of knowledge management studies. Program: Electronic Library and Information Systems, 49(3), 325-342.

BreakFast (2016). Ukraina v Globalnom reytinge innovatsiy [Ukraine in the Global ranking of innovations]. Retrieved from http://www.break-fast.com.ua/ukrainav-mirovom-rejtinge-innovacij/

Bučková, J. (2015). Corporate culture as an important factor in the implementation of knowledge management. Forum Scientiae Oeconomia, 3(3), 5161.

Downs J. B., Hossfeld, O., \& Velamuri, V. K. (2019). The ECLQO five-factor framework: An alternative lens for business model innovation in highly knowledge-intensive industries. Managerial and Decision Economics, 40(3), 309-320.

European Innovation Scoreboard (2016). Retrieved from http://ec.europa.eu/growth/industry/innovation/ facts-figures/scoreboards_en

European Innovation Scoreboard (2018). Retrieved from http://ec.europa.eu/growth/industry/innovation/ facts-figures/scoreboards_en

Eurostat (2019). Retrieved from https://ec.europa.eu/eurostat

Fini, R., Rasmussen, E., Siegel, D., \& Wiklund, J. (2018). Rethinking the Commercialization of Public Science: From Entrepreneurial Outcomes to Societal Impacts. Academy of Management Perspectives, 32(1). doi: 10.5465/amp.2017.0206

Fitri, H., Nugraha, A. T., Hakimah, Y., \& Manihuruk, Ch. (2019). Strategic Management of Organizational Knowledge and Competency Through Intellectual Capital. Polish Journal of Management Studies, 19(2), 132-141. doi: 10.17512/pjms.2019.19.2.11

Formánek, I. (2015). Knowledge management as an important part of strategic management. Forum Scientiae Oeconomia, 3(3), 45-50.

Ibidunni, A. S., Olokundun, M. A., Motilewa, D. B., Atolagbe, T. M., \& Osibanjo, O. A. (2018). Group-tacit knowledge and organisational effectiveness: analysis of effects using a mixed method approach. Business: Theory and Practice, 19, 135-145. doi: 10.3846/ btp. 2018.14

Illiashenko, N. S. (2019). Upravlinnya vyperedzhayuchym innovatsiynym rozvytkom promyslovykh pidpryyemstv [Management of advanced innovative development of industrial enterprises]. Sumy, Ukraine: Trytoria.

Illiashenko, S., \& Rot-Sierov, Y. (2016). Knowledge as a factor of organization's competitive benefits: prospects for Ukraine. Economic Annals-XX, 156(1-2), 49-53.

Industriya $4.0 \mathrm{v}$ Ukrayini (2018). Industriya $4.0 \mathrm{v}$ mashynobuduvanni. Stan $v$ Ukrayini ta perspektyvy rozvytku
[Industry 4.0 in machine-building industry. State of Ukraine and prospects for development]. Retrieved from https://industry4-0-ukraine.com.ua/

Informator (2019). Bloomberg nazvav novu pozytsiyu Ukrayiny u reytynhu naybil'sh innovatsiynykh ekonomik svitu [Bloomberg has announced Ukraine's new ranking in the rating of the most innovative economies in the world]. Retrieved from https://informator. news/bloomberg-nazvav-novu-pozytsiyu-ukrajinyu-rejty nhu-najbilsh-innovatsijnyh-ekonomik-svitu/

Instytut ekonomichnykh doslidzhen' ta politychnykh konsul'tatsiy (2016). Shchorichna otsinka dilovoho klimatu [Annual assessment of the business climate]. Retrieved from http://www.ier.com.ua/ua/sme_development/ABCA?pid=6494

Khedhaouria, A. \& Jamal, A. (2015). Sourcing knowledge for innovation: knowledge reuse and creation in project teams. Journal of Knowledge Management, 19(5), 932-948.

Kovtunenko, Yu. V. (2012). Osoblyvosti orhanizatsiyi protsesu komertsializatsiyi innovatsiynykh rozrobok vysokotekhnolohichnykh pidpryyemstv [Organization features of the commercialization process of high-tech enterprises' innovations]. Pratsi Odes'koho politekhnichnoho universytetu, 2(39), 313-317.

Kuzmin A. E., \& Kostsyk R. S. (2013). Vybir metodiv komertsializatsii innovatsiinoi produktsii pidpryiemstv [The choice of commercialization methods of enterprises innovative products]. Ekonomika ta derzhava, 9, 6-8.

Landry, R., \& Amara, N. (2012). Elucidation and enhancement of knowledge and technology transfer business models. VINE: The Journal of Information and Knowledge Management Systems, 42(1), 94-116. doi: 10.1108/03055721211207789.

Maceika, A., \& Jančiauskas, B. (2012). Innovative knowledge: its origin, detachment and usage in production practice. Business: Theory and Practice, 13(3), 228233. doi: $10.3846 /$ btp. 2012.24

Majewska, M., \& Szulczyńska, U. (2014). Methods and Practices of Tacit Knowledge Sharing Within an Enterprise: an Empirical Investigation. Oeconomia Copernicana, 5(2), 35-48. doi: 10.12775/ OeC.2014.012

Mardania, A., Nikoosokhanb, S., Moradib, M., \& Doustarb, M. (2018). The Relationship Between Knowledge Management and Innovation Performance. The Journal of High Technology Management Research, 29(1), 12-26.

Markman, G. D., Siegel, D. S., \& Wright, M. (2008). Research and Technology Commercialization. Journal of Management Studies, 45(8), 1401-1423.

Massingham, P. (2014). An evaluation of knowledge management tools: Part 1 - managing knowledge resources. Journal of Knowledge Management, 18(6), 1075-1100. doi: 10.1108/JKM-11-2013-0449

Naqshbandib, M. M., \& Jasimuddin, S. M. (2018). Knowledge-oriented leadership and open innovation: Role of knowledge management capability in Francebased multinationals. International Business Review, 27(3), 701-713.

Olefirenko, O. M. (2016). Komertsializatsiya innovatsiy yak obyektyvnyy chynnyk efektyvnoho funktsionuvan- 
nya promyslovoho pidpryyemstva [Commercialization of innovations as an objective factor of effective functioning of an industrial enterprise]. Skhidna Yevropa: ekonomika, biznes ta upravlinnya, 5(05), 179-183.

Olefirenko, O. M. (2017). Upravlinnya komertsializatsiyeyu innovatsiy promyslovykh pidpryyemstv: aspekty zbutovoyi polityky [Management of commercialization of innovations of industrial enterprises: aspects of sales policy]. Sumy, Ukraine: Trytoria.

Prokopenko, O., Holmberg, R., \& Omelyanenko, V. (2018). Information and communication technologies support for the participation of universities in innovation networks (comparative study). Innovative Marketing, 14(3), 17-29.

Ringel, M., Manly, J., \& Möller, C. (2018). The Most Innovative Companies 2018. Retrieved from https://www. bcg.com/publications/collections/most-innovativecompanies-2018

Rot-Sierov, Ye. V. (2016). Rol i mistse znan u komertsializatsiyi innovatsiy yak instrumentu realizatsiyi potentsialu pidpryyemstva [The role and place of knowledge in the commercialization of innovations as a tool for realization of enterprise potential]. Prychornomors'ki ekonomichni studiyi, 12(2), 33-37.

Shypulina, Yu. S. (2017). Upravlinnya rozvytkom innovatsiynoyi kul'tury promyslovykh pidpryyemstv [Management of development of innovative culture of industrial enterprises]. Sumy, Ukraine: TOV “Trytoria”.

Soskin, O. I. (2014). Narodnyy kapitalizm: ekonomichna model dlya Ukrayiny [People's capitalism: an economic model for Ukraine]. Kyiv, Ukraine: Vydavnyctvo "IST".

Stankiewicz, J. S., \& Moczulska, M. (2015). The involvement of employees in knowledge management in the light of the research results. Oeconomia Copernicana, 6(2), 37-51. doi: 10.12775/OeC.2015.011

State Statistics Service of Ukraine [Derzhavna sluzhba statystyky Ukrayiny] (2019). Retrieved from http:// www.ukrstat.gov.ua/

The Global Innovation Index (2019). Retrieved from https://www.globalinnovationindex.org/analysisindicator.

Turkey: WIPO Releases (2018). World Intellectual Property Indicators Report. Retrieved from http://www. mondaq.com/turkey/x/782720/ Trademark/WIPO+ Releases+2018+World+Intellectual+Property+Indic ators+Report

Ukrstat (2018). Naukova ta innovatsiyna diyalnist Ukrayiny: statystychnyy zbirnyk [Scientific and innovative activity of Ukraine: statistical yearbook]. Kyiv, Ukraine: Derzhavna sluzhba statystyky Ukrayiny. Retrieved from https://ukrstat.org/uk/druk/publicat/kat_u/2018/zb/09/zb_nauka_2017.pdf

Ukrstat (2019). Naukova ta innovatsiyna diyalnist Ukrayiny: statystychnyy zbirnyk [Scientific and innovative activity of Ukraine: statistical yearbook]. Kyiv, Ukraine: Derzhavna sluzhba statystyky Ukrayiny. Retrieved from http://www.ukrstat.gov.ua/druk/ publicat/kat_u/2019/zb/09/zb_nauka_2018.pdf

World Intellectual Property Organization (2019). Retrieved from https://www3.wipo.int/ipstats/keysearch.htm? keyId=231
Yahiaei, M., \& Hasanzadeh, A. (2018). Presentation a technology commercialization model in ICT knowledge base companies. Investment Knowledge, 7(26), 63-82.

Zahra, S. A., Kaul, A., \& Bolívar-Ramos, M. T. (2018). Why Corporate Science Commercialization Fails: Integrating Diverse Perspectives. Academy of Management Perspectives, 32(1). Retrieved from https:// journals.aom.org/doi/10.5465/amp.2016.0132 